\title{
The effect of mineral fertilizers on the yield of vegetable beans, depending on the competition between plants in crops
}

\author{
Natalya Varfolomeyeva ${ }^{1,{ }^{*}}$, Elena Blagorodova $^{1}$, Anastasiya Zvyagina $^{1}$, and Tamara \\ Nepshekueva $^{1}$ \\ ${ }^{1}$ Kuban State Agrarian University, 13, Kalinin str., 350044 Krasnodar, Russia
}

\begin{abstract}
The sources of nutrient accumulation in beans and bean seeds are the process of photosynthesis, root nutrition during the seed filling period, as well as the reutilization of substances accumulated in the vegetative organs in the previous period. The close dependence of the competition intensity on the number of plants per unit area of sowing is revealed. It was found that although increased nitrogen doses significantly reduce the competitive mutual inhibition of plants, it begins earlier than with a low nitrogen nutrition level. The main factor for which bean plants compete during the emergence-beginning of flowering phase under normal cultivation conditions is the available soil nitrogen. Therefore, the nitrogen fertilizers rational use leads to a more complete phenotypic manifestation of the vegetable beans genetically determined productivity.
\end{abstract}

\section{The value of the data}

- These data contain recommendations for bean sowing schemes to ensure optimal feeding area for plants.

- These data can be useful for understanding the effect of the solution concentration used in foliar nutrition on the total nitrogen, starch, protein and dry matter content in seeds.

- These data can be actively used to determine the timing and rates of mineral nutrition application to plants.

- The data obtained can support agricultural researchers working in the field of legumes vegetable production.

\section{Data Description}

Increasing the area under leguminous vegetable crops, sources of vegetable protein, is one of the most difficult crop production problems due to the fact that the correlation between yield

*Corresponding author: varfolomeeva_ni@mail.ru 
and protein content in grain often has a negative value, increasing the yield of legumes does not lead to an increase in the amino acids content in beans. The solution of this problem is carried out by scientists in two main directions: selection and genetic and technological. It was found that climatic and agrotechnical conditions have a stronger influence on the variation of the nitrogen content in the grain than on the variety genotypic features, as well as on the degree of disease spread. [1-3].

To date, the domestic and foreign literature has accumulated quite significant material on the effect of foliar application of mineral substances on the acceleration of plant growth and development, increasing winter hardiness and resistance to diseases, prolonging the leaves life, on the qualitative and quantitative increase in the grain, vegetable, industrial and fruit crops yield. In their works, scientists note the possibility of obtaining legumes and vegetables high-protein crop without using nitrogen fertilizers or with their minimal use. However, researchers have different views on this issue, considering that legumes, under favorable conditions, can absorb up to $2 / 3$ of the crop forming nitrogen from the air [4-5].

Augustine Apiamu points to the main goal of breeding - high plant productivity and the fact that in the process of crop formation, legumes use the host plant photosynthesis products. The author notes that modern pea varieties have a higher activity of the nitrogen-reducing enzymatic system compared to the earlier bred varieties [6].

Foreign authors note the effectiveness of small mineral nitrogen doses (N30-45) under leguminous crops in 2-4 weeks after seedlings emergence, in the phases of plant growth beginning and active nodules functioning. The absence of harm and stimulation of symbiotic relationships between gram-negative soil bacteria and leguminous plants are noted [2-7].

The co introduction of nitrogen in soybean varieties cultivation promoted the increase of nitrogen fixation in comparison with the control variant from 55 to $139 \%$; in lupine nitrogen fertilization did not reduce nitrogen-fixing ability, feasibility of using nitrogen fertilization for peas was noted when grown on poor sandy loam soddy-podzolic and gray forest soils. However, other authors did not find any positive effect of nitrogen fertilizers on the peas yield on ordinary and leached chernozems, sandy loam and gray forest soils [3-8].

It is known that during the legumes growth and development, nodule bacteria actively use photosynthesis products, nitrogen symbiotic fixation changes and, in the transition to the plant reproductive development, reaches the highest indicators of functional activity. In the early plants fruiting phase the main current of photosynthesis products is directed to the forming seeds, where the concentration of hormones, stimulants become the highest, and the transportation of photosynthesis products from leaves to roots and nodules decreases, which leads to aging and nodules activity reducing [9-11].

In the works of Chaer, G.M. et al. it is noted that the intensity of nitrogen accumulation in plants is more controlled by the photosynthesis intensity, and the intake of carbohydrates from the leaves to the nodules is considered as one of the main factors limiting the nitrogen accumulation process in legumes [9]. According to the data presented by Rafael Sanches researching early-maturing vegetable peas varieties, it was noted that the plants had 65-75 days growing season and the size of biomass and nitrogen accumulation in them was limited, but, in comparison with the early selection varieties, the plant mass did not increase, and the yield increase occurred was due to the grain share in the biomass increase by 1.5-2 times [8$12]$.

Researches by Reinprecht et al. confirm the photosynthesis process, root nutrition in the seed filling period, as well as the reutilization of substances accumulated in the vegetative organs in the previous period as a source of nutrient accumulation in seeds. The main nitrogen portion $(70-80 \%)$ is delivered to the plants of peas, vegetable beans before the seed filling start, and only $30 \%$ - in the subsequent period. Thus, in the fruit formation period, plants make maximum use of their own internal nitrogen reserves from the vegetative organs for seed formation. [13] 
In turn, as is noted by Reinprecht et al., the insufficient supply of nitrogen from the root system to the aboveground organs negatively affects photosynthesis, accelerates the leaves aging process, and reduces their active functioning time. Moreover, such a sequence of the pointed interdependent processes is subject to general ontogenetic patterns, regardless of the availability of plant nutrients [13].

S. J. Habinshuti, S. T. Maseko, F. D. Dakora have studied the influence of late non-root nitrogen fertilization on the symbiotic activity of legumes. The authors noted the depressing effect on this process of pre-sowing fertilization in the soil, especially in high doses. However, the effect of foliar fertilization on nitrogen accumulation has not yet been sufficiently studied [14].

Schwember et al. have established that in years with sufficient precipitation soybeans foliar fertilization during in the period of beans formation had led to the increase in the maximum nitrogen accumulation by plants an average of $16.5 \%$ and the increase in seed yield - by 3.5 c / ha [15]. According to S. J. Habinshuti S. T. Maseko F. D. Dakora, late soybeans foliar fertilizing with a liquid complex fertilizer carried out in the seed filling period, improved photosynthetic activity, significantly increased the biological yield (by $0.12-0.25 \mathrm{t}$ / ha) and the protein content in soybean seeds (by $1.3 \%$ ).

Schwember et al. have established that non-root feeding of vegetable beans with urea carried out during the flowering period did not have a depressing effect on the symbiotic nitrogen fixation, and can serve as an alternative method of nitrogen fertilizers using in leguminous crops cultivation [15].

The effect of late non-root vegetable beans fertilizing has not been sufficiently studied. S. J. Habinshuti S. T. Maseko F. D. Dakora have established that the bean plant absorbs nitrogen in the form of urea better when used as foliar top dressing. Leaf feeding with urea gives a much greater increase in yield than applying the same amount of fertilizers to the soil $[16,17]$.

Leaf feeding of vegetable beans with ammonium sulphate in the flowering beginning increases the photosynthesis intensity by $33 \%$, the nitrogen content in the plant - by $80 \%$, and in the leaves - by $52 \%$ [3].

We studied the effect of mineral fertilizers on the yield of vegetable beans, depending on the competition between plants in crops in the central zone of the Krasnodar Territory.

\section{Experiment Design, Materials, and Methods}

\subsection{Field and vegetation experiments}

Vegetation experiments were laid in vessels with soil culture $(6 \mathrm{~kg})$ on Pryanishnikov mixture, in which nitrogen was present in the form of ammonium sulfate (double dose).

Field experiments were carried out at an experimental site on the outskirts of the city of Krasnodar, the Krasnodar Territory. The research was conducted in the field experiment in 2018-2019. The area of the experimental plots was $100 \mathrm{~m}^{2}$, the arrangement - tiered, systematic, the repetition was fourfold.

\subsection{Object of research}

The object of the study is the vegetable bean variety Snezhana. The plant has a bush shape, does not lie down. The variety of the FSBScI Rice Research Institute selection is characterized by medium-ripeness, high yield, low bacterial spotting, relative resistance to viral mosaics, bean resistance to cracking, erect bush type, high attachment of beans above the soil surface. All these advantages provide combine harvesting with minimal losses and 
are important economic valuable features when growing this vegetable beans variety in the conditions of Kuban.

\subsection{Research methodology. Discussion of the results}

On the chernozem soil, ordinary beans were sown in several seeding methods: wide-row (45 $\times 15$ and $70 \times 15)$ and double-row tapes $(50+20 \times 15$ and $90+50 \times 15)$ at densities of $10,15,19$ plants per $1 \mathrm{~m}^{2}$ on two backgrounds of nitrogen fertilizer: $27.6 \mathrm{~g}$ and $110.4 \mathrm{~g}$ of ammonium sulfate per $1 \mathrm{~m}^{2}$. In order to study the degree of competitive mutual influence of plants, depending on the sowing density and nitrogen dose, samples were taken for analysis three times at the beginning of branching (the appearance of side shoots) (July 6) and in 10 and 20 days (July 16 and 26). With a low level of nitrogen nutrition and the density of 15 and 19 plants per $1 \mathrm{~m}^{2}$, mutual inhibition of plants was observed already at the very beginning of the lateral shoots appearance. At the lower densities $\left(10\right.$ plants per $\left.1 \mathrm{~m}^{2}\right)$, the amount of dry biomass per 1 plant did not increase, and, therefore, in such scarce crops, there was still no mutual plants suppression. The increase in nitrogen nutrition largely compensates for the decrease in plant weight due to mutual suppression. Thus, plants growing at the seeding density of 19 plants per $1 \mathrm{~m}^{2}$, and the dose of $110.4 \mathrm{~g} / \mathrm{m}^{2}$ of ammonium sulfate by dry weight were close to the plants of 4 times scarcer seeding against a background of $27.6 \mathrm{~g} / \mathrm{m}^{2}$ $\left(\mathrm{NH}_{4}\right)_{2} \mathrm{SO}_{4}$, and with 15 plants per $1 \mathrm{~m}^{2}$ their weight under conditions of high nitrogen dose was equal to the weight of plants growing at the density of 10 plants per $1 \mathrm{~m}^{2}$, and 4 times less provided with nitrogen fertilizer.

The most important reason holding back the increase in bean yields is the sparseness of its crops. By increasing the seeding rates and other agricultural practices, it is not always possible to ensure the optimal density of plants standing on production bean crops. Therefore, the possibility of increasing the plants standing density through increasing the bushiness acquires practical significance.

A characteristic hereditary feature of bean plants is the ability to form a large number of branching shoots under favorable conditions due to pinching. In one of our experiments, with the density of 14 plants per $1 \mathrm{~m}^{2}$ and optimal dose of nitrogen, bean plants formed an average of more than 30 branching shoots. Under normal conditions, these genetically determined potencies are realized only by $10-20 \%$. Studies have shown that the main reason for this is the competition between neighboring plants for limiting environmental factors in the early phases of the growing season, and especially as the size of plants increases and the habitat resources are depleted. To find ways to control the branching process, it is necessary to know the patterns of competitive relationships between bean plants in crops of different densities and to identify environmental factors for which plants compete first of all.

The results of our research allow us to draw a fundamentally important conclusion: although increased doses of nitrogen significantly reduce the competitive mutual plants inhibition, it begins earlier than with a low level of nitrogen nutrition. Thus, at the high nitrogen dose at the beginning of branching, competition is already observed at the density of 10 to 15 plants per $1 \mathrm{~m}^{2}$, and at the low nitrogen dose at the same density limits there is no mutual suppression of plants by this time. This fact, discovered for the first time, is obviously explained by the fact that the degree of competition is proportional to the amount of biomass per sowing area unit, and the decrease for nitrogen delivery increases competition between plants for other factors.

In 10 days after the appearance of first-order lateral branches, competition increases, as is evidenced by more significant differences in the weight of biomass between plants of different crop density variants, as well as a more pronounced hyperbolic nature of the corresponding dependencies. 
A decrease in the degree of inhibition of plant growth under the influence of an increased dose of nitrogen is even more pronounced, although the ratio noted at the beginning of tillering remains: a 4 times increase of the nitrogen fertilizer dose provides the same weight of plants as a 4 times increase of the feeding area at the low nitrogen dose. This gives reason to believe that when growing beans in the central zone of the Krasnodar Territory, on ordinary chernozem, the main factor for which plants compete is nitrogen.

In the flowering phase (on the 20th day after its start), due to the increase in the size of plants, as well as their requirements for environmental resources, competition in crops increased even more. And, accordingly, the differences in plant weight were more pronounced depending on the nitrogen nutrition level.

When considering the same data at the crop level, the usual dependence of the biomass yield per unit area of the crop on its density appeared for competing communities. At the same time, there was an increase in the positive effect of nitrogen fertilizer increased dose as the crop density increased $(45 \times 15$ and $50+20 \times 15 \mathrm{~cm})$. The limit to which the biomass yield tends as it thickens is largely determined by the level of nitrogen nutrition: it is approximately three times higher at the ammonium sulfate dose of $110.4 \mathrm{~g} / \mathrm{m}^{2}$ than at the dose of $27.6 \mathrm{~g} / \mathrm{m}^{2}$. This once again confirms the conclusion that the main limiting factor for which bean plants compete during the tillering period is the available soil nitrogen.

According to the literature, plants can compete not only for nitrogen, but for soil water, light, and phosphorus as well [17]. In irrigated beans cultivation competition for water is excluded, but is possible for light and phosphorus. The measure of competition for light is the value of the leaf surface index (leaf index), i.e. the total leaves area of the seeding plants per $1 \mathrm{~m}^{2}$ of the soil surface. Special observations showed that at the dose of ammonium sulfate $27,6 \mathrm{~g} / \mathrm{m}^{2}$ mutual suppression of plants as planting density thickens cannot be explained by the competition between them for the light, since at the beginning of the period from germination to the beginning of flowering the value of the index even with 15 plants per $1 \mathrm{~m}^{2}$ is not reached $2.5 \mathrm{~m}^{2}$ of leaf surface per $1 \mathrm{~m}^{2}$, and by the middle of the flowering phase made up only $2.9 \mathrm{~m}^{2}$. Significant competition for light is observed only when the leaf surface index is $3.78 \mathrm{~m}^{2}$ or more. The indexes reached these values only at the background of $110,4 \mathrm{~g} / \mathrm{m}^{2}$ of ammonium sulfate introduction in the flowering phase at the density of 19 plants per $1 \mathrm{~m}^{2}$, in 10 days - at a density of 15 plants per $1 \mathrm{~m}^{2}$ and at the end of the flowering period - at densities of 10 and 15 plants per $1 \mathrm{~m}^{2}$. Consequently, the weakening of competition between plants for nitrogen leads to their mutual shading and competition for light increase.

In order to test the possibility of competition between plants for phosphorus with the abundant nitrogen supply under the same conditions, another experiment was conducted. The control was the application of nitrogen and phosphorus fertilizers in the doses of N-5.85 g / $\mathrm{m}^{2}$ and $\mathrm{P}_{2} \mathrm{O}_{5}-8.49 \mathrm{~g} / \mathrm{m}^{2}$. The unilateral doubling of the nitrogen fertilizer dose led to the almost 2-fold increase in the grain yield per unit of area sown, mainly due to the growth of side shoots of the first, second and third orders and, to a lesser extent, to the beans grain content increase. Doubling the phosphorus fertilizer dose against the background of nitrogen double dose did not lead to increased branching and reduced the beans grain content. Consequently, the studied soil contained a sufficient amount of phosphorus, and its additional application did not weaken the competition between plants. Table 1 shows the data on the fertilizers effect on the beans productivity, depending on the sowing density.

Table 1. The effect of nitrogen and phosphorus fertilizers on the beans productivity depending on the crop density (average for 2018-2019)

\begin{tabular}{|l|l|l|}
\hline & & Bean productivity \\
\hline
\end{tabular}




\begin{tabular}{|c|c|c|c|c|c|}
\hline $\begin{array}{l}\text { Nitrogen and } \\
\text { phosphorus } \\
\text { dose, } \mathrm{g} / \mathrm{m}^{2} \\
\text { of the active } \\
\text { substance }\end{array}$ & $\begin{array}{l}\text { Number } \\
\text { of plants } \\
\text { per } m 2\end{array}$ & $\begin{array}{l}\text { Number of } \\
\text { beans per } \\
\text { plant, pcs. }\end{array}$ & $\begin{array}{c}\text { Average } \\
\text { number of } \\
\text { seeds per } 1 \\
\text { plant, pcs. }\end{array}$ & $\begin{array}{c}\text { Weight of } \\
1000 \\
\text { seeds, g }\end{array}$ & $\begin{array}{l}\text { Seed yield, } \\
\mathrm{g} / \mathrm{m}^{2}\end{array}$ \\
\hline \multirow{3}{*}{$\begin{array}{l}23,40 \mathrm{~g} \mathrm{~N}+ \\
8,49 \mathrm{~g} \mathrm{P}_{2} \mathrm{O}_{5}\end{array}$} & 19 & 16 & 62 & 459.1 & 816.2 \\
\hline & 15 & 19 & 93 & 466.0 & 768.6 \\
\hline & 10 & 21 & 102 & 463.5 & 725.2 \\
\hline \multirow{3}{*}{$\begin{array}{l}46,8 \mathrm{~g} \mathrm{~N}+ \\
8,49 \mathrm{~g} \mathrm{P}_{2} \mathrm{O}_{5-}\end{array}$} & 19 & 22 & 95 & 498.2 & 1218.7 \\
\hline & 15 & 25 & 104 & 471.1 & 1191.8 \\
\hline & 10 & 27 & 159 & 488.4 & 985.6 \\
\hline \multirow{3}{*}{$\begin{array}{l}46,8 \mathrm{~g} \mathrm{~N}+ \\
16,97 \mathrm{~g} \mathrm{P}_{2} \mathrm{O}_{5}\end{array}$} & 19 & 23 & 84 & 468.1 & 898.8 \\
\hline & 15 & 26 & 96 & 454.9 & 838.6 \\
\hline & 10 & 29 & 172 & 453.6 & 802.2 \\
\hline
\end{tabular}

From table 1 it is seen that with the double decrease of the seeding density the productivity of the studied beans plants and the elements of its structure (number of beans and seeds per plant, number of seeds per pod and weight of 1000 seeds and seed yield per $1 \mathrm{~m}^{2}$ increases by about one and half times and to a lesser extent, increases the grain content of the beans. And an increase in the area of plant nutrition by 1,3-1,9 times increases the productivity of beans and leads to further increase in the beans grain content. As a result of this sparseness, the seed yield per unit of area under cultivation is reduced to a relatively small extent. This means that under favorable conditions, bean plants show a high ability to compensate for a decrease in crop density by increasing other elements of the crop structure. Only the weight of seeds on sparse crops not only does not increase, but even there is a tendency to its reduction.

The above indicates that the plants of ordinary bean crops density compete primarily for nitrogen from the very beginning of the flowering phase. This process progressively increases during the entire period of lateral shoots' formation. Thus, the close dependence of competition intensity on the number of plants per unit of area under cultivation is revealed. Due to the increase of plant biomass and depletion of the environment by the middle and the end of the flowering phase the inverse dependence of plants branching on crop density is more pronounced, the sharper is the role of nitrogen nutrition conditions in the reduction of the competition suppressing effect on the intensity of branching. As in the case of a biomass crop, a similar ratio is found here: 4 times increase of the nitrogen fertilizer dose provides the same or even more intensive tillering, as well as 1.3 or 1.9 times increase of the nutrition area per plant with a low nitrogen dose. This means that by reducing the intensity of competition for the main growth-limiting factor - nitrogen - it is possible to largely neutralize the competitive stress effect and thereby more fully identify the potential genetic productivity of vegetable bean plants.

When calculated per 1 plant, the greatest increase in the number of the first, second and third order shoots under the influence of an increased nitrogen dose is observed in plants of scarce crops. However, as shown above, the total effect of an increased dose of fertilizer on plants growing on $1 \mathrm{~m}^{2}$ of sowing is higher on dense crops due to increased competition for nitrogen as the crops thicken, but from a production point of view, a more important indicator is not the number of shoots per 1 plant, but their number per $1 \mathrm{~m}^{2}$ of sowing, since this determines the contribution of the branching process to the overall productivity of vegetable beans. At a low nitrogen dose, the largest number of branches per area unit is formed by crops with a density of 10 plants per $1 \mathrm{~m}^{2}$, with a sowing pattern of $90+50 \times 15 \mathrm{~cm}$, and with a greater thickening the contribution of this process to the total number of branches decreases. Against the background of the increased nitrogen dose, the total number of dense crops 
branches increases to a much greater extent than scarce ones, although the number of branches is added to scarce crops per plant. This indicates the fallacy of the widely held view that nitrogen fertilizer is a specific means of enhancing the branching of scarce crops. On the contrary, the optimal density, at which the greatest contribution of branches to the overall productivity is achieved, may increase as nitrogen feeding conditions improve. If with 27,6 $\mathrm{g} / \mathrm{m}^{2}$ of ammonium sulfate the maximum number of branches per plant per $1 \mathrm{~m}^{2}$ was observed at the density of 10 plants per $1 \mathrm{~m}^{2}$, with the fertilizer dose of $110,4 \mathrm{~g} / \mathrm{m}^{2}$ such a maximum is detected at the end of the flowering phase with the density of about 19 plants per $1 \mathrm{~m}^{2}$. However, even in scarce crops, under the influence of an increased dose of nitrogen, the number of branches on plants per unit area under cultivation increased.

In order to study the effect of non-root feeding for beans productivity and chemical composition we have conducted an experiment. At the age of 5-6 real leaves, they were sprayed with solutions of ammonium nitrate (in vegetation experiments at the rate of $2.5 \mathrm{ml}$ per vessel, in field experiments - 400 1/ha). Seed samples were taken in two periods: at the stage of milk ripeness (young beans) and at the harvesting time. For biochemical analyses, the seeds were fixed with absolute alcohol, followed by lyophilic drying. In the fresh material grain content of beans, the absolute weight of seeds, their physiological maturity were determined, and beans yielding capacity in field experiments - by taking trial plants from 1 $\mathrm{m}^{2}$ in six spots of experimental plots. Bean bushes were pulled out together with the root system, and were let to mature for a week in a dry, ventilated room. After plants drying the beans were separated from the bush, the total number of beans was counted, as well as the percentage of certified beans, the number of beans per plant, the number of certified beans, the beans total on the same plant, the mass of the standard of beans per plant, weight of seeds collected from $1 \mathrm{~m}^{2}$ and counted per 1 ha. The vegetable beans growing season was 110 days. The research results were subjected to statistical analysis using the dispersion method; the value of the smallest significant difference between the variants is given at the probability level of $0.95\left(\mathrm{HCP}_{0,95}\right)$

Table 2. The effect of non-root nitrogen application on beans productivity (vegetation experiments), (average for 2018-2019)

\begin{tabular}{|l|c|c|c|c|c|}
\hline \multicolumn{1}{|c|}{ Treatments } & $\begin{array}{c}\text { Weight of } \\
1000 \text { seeds } \\
\text { at 14\% } \\
\text { humidity, g }\end{array}$ & $\begin{array}{c}\text { Weight of } \\
1000 \\
\text { seeds, \% } \\
\text { to control }\end{array}$ & $\begin{array}{c}\text { Weight of } \\
\text { seeds } \\
\text { from 1 } \\
\text { plant at 14 } \\
\% \\
\text { humidity, g }\end{array}$ & $\begin{array}{c}\text { Weight of } \\
\text { seeds } \\
\text { from 1 } \\
\text { plant, \% to } \\
\text { control }\end{array}$ & $\begin{array}{c}\text { Blind seed } \\
\text { disease \% }\end{array}$ \\
\hline $\begin{array}{l}\text { Control (treated } \\
\text { with water) }\end{array}$ & 466.2 & 100.0 & 53.6 & 100.0 & 13.3 \\
\hline $\begin{array}{l}5 \% \text { solution of } \\
\mathrm{NH}_{4} \mathrm{NO}_{3}\end{array}$ & 473.4 & 101.5 & 54.9 & 102.4 & 12.1 \\
\hline $\begin{array}{l}10 \% \text { solution } \\
\text { of } \mathrm{NH}_{4} \mathrm{NO}_{3}\end{array}$ & 486.5 & 104.3 & 59.3 & 110.6 & 10.4 \\
\hline $\begin{array}{l}15 \% \text { solution } \\
\text { of } \mathrm{NH}_{4} \mathrm{NO}_{3}\end{array}$ & 498.2 & 106.8 & 65.2 & 121.6 & 10.2 \\
\hline $\mathrm{HCP}_{0,95}$ & 0.67 & & 1.95 & & \\
\hline
\end{tabular}

Table 2 shows that to obtain a reliable increase in yield, it is necessary to use high fertilizer concentrations. Spraying with a 5\% solution of ammonium nitrate did not cause any increase in beans yield. The maximum yield was obtained when treated with a $15 \%$ solution of $\mathrm{NH}_{4} \mathrm{NO}_{3}$ (seed weight has increased and seed blindness has slightly decreased). 
In the theory of non-root plants nutrition there are two points of view on the physiological role of substances introduced through the leaf. Some researchers $[6,8]$ consider the effect of foliar fertilizing to be based on the irritation of the cell plasma caused by mineral nutrients through the leaf and causing outbreak of physiological and biochemical processes (photosynthesis, respiration, activity of enzyme systems, etc.); others [12,18] believe that foliar nutrition should be considered more as an additional to the root one.

In our opinion, when foliar fertilizers are applied, there is both irritation of the cell plasma and the use of mineral elements as additional nutrition. This point of view is confirmed by simple calculations. If we take as a basis that bean seed contains $12-15 \%$ of total nitrogen, then for the formation of $1 \mathrm{~g}$ of seeds, $0.12-0.15 \mathrm{~g}$ of nitrogen is required. $2.5 \mathrm{ml}$ of $15 \%$ ammonium nitrate contains $127 \mathrm{mg}$ of nitrogen, which can provide $17.1 \mathrm{~g}$ of grain formation. In our experiments, the maximum yield increase per plant was $11.6 \mathrm{~g}$. Thus, even if we assume that all the nitrogen introduced through the leaves is used for the formation of the crop, which is unlikely, it still cannot ensure the formation of the number of seeds equal to the maximum increase. Therefore, we believe that mineral elements introduced through the leaf act both as additional nutrition and as an irritant factor.

When studying the dynamics of the accumulation of dry matter in bean seeds under the influence of foliar feeding, it turned out that in the milk ripeness phase, the weight of absolutely dry seeds from plants treated with 5, 10 and 15\% solution of nitric acid ammonium was higher than the control ones by 7, 19 and $41 \%$, respectively. In the process of seed maturation, this difference was smoothed out and in the full ripeness (biological) phase was 1,7 and $12 \%$, respectively. Apparently, ammonium nitrate, being involved in synthetic processes leading to the formation of protein substances, is not only an additional source of nutrition, but also an amplifier of hydrolytic processes in bean leaves, which contributes to a better outflow of plastic substances to seed.

Treatment of plants with ammonium nitrate solution in the field conditions gave the same results as in the vegetation ones (Table 3 ).

Table 3. Effect of foliar nitrogen fertilization on bean yield (field experiments) (average 2018-2019)

\begin{tabular}{|l|c|c|c|c|c|c|c|c|}
\hline $\begin{array}{c}\text { Treatment } \\
\mathrm{s}\end{array}$ & $\begin{array}{c}1000 \\
\text { grains } \\
\text { weight } \\
\text { at } 14 \% \\
\text { humidit } \\
\mathrm{y}\end{array}$ & $\begin{array}{c}1000 \\
\text { grains } \\
\text { weight } \\
\% \text { to } \\
\text { contro } \\
1\end{array}$ & $\begin{array}{c}\text { Yield } \\
\text { per 1 } \\
\mathrm{m}^{2}, \mathrm{~g}\end{array}$ & $\begin{array}{c}\text { Yield, } \\
\mathrm{c} / \text { ha }\end{array}$ & $\begin{array}{c}\text { Num- } \\
\text { ber of } \\
\text { beans } \\
\text { per } \\
\text { plant, } \\
\text { pcs. }\end{array}$ & $\begin{array}{c}\text { Marke- } \\
\text { tability, } \\
\%\end{array}$ & $\begin{array}{c}\text { Num- } \\
\text { ber of } \\
\text { plants } \\
\text { per 1 } \\
\mathrm{m}^{2}\end{array}$ & $\begin{array}{c}\text { Product } \\
\text { ive } \\
\text { bushine } \\
\text { ss }\end{array}$ \\
\hline $\begin{array}{l}\text { Control } \\
\text { treated } \\
\text { with } \\
\text { water) }\end{array}$ & 484.9 & 100.0 & 260.5 & 26.05 & 25.5 & 98.8 & 14 & 2,1 \\
\hline $\begin{array}{l}5 \% \\
\text { solution of } \\
\mathrm{NH}_{4} \mathrm{NO}_{3}\end{array}$ & 489.3 & 100.9 & 271.7 & 27.17 & 27.1 & 98.8 & 14 & 2,1 \\
\hline $\begin{array}{l}10 \% \\
\text { solution of } \\
\mathrm{NH}_{4} \mathrm{NO}_{3}\end{array}$ & 528.1 & 108.9 & 299.6 & 29.96 & 29.4 & 98.8 & 14 & 2,1 \\
\hline $\begin{array}{l}15 \% \\
\text { solution of } \\
\mathrm{NH}_{4} \mathrm{NO}_{3}\end{array}$ & 551.8 & 113.8 & 359.3 & 35.93 & 33.5 & 98.8 & 14 & 2,1 \\
\hline $\mathrm{HCP}_{0,95}$ & 0.74 & & 31 & & & & & \\
\hline
\end{tabular}

Beans chemical composition under the influence of nitrogen foliar feeding changed slightly (Table 4). Only the content of total nitrogen, protein, starch and dry substances increases slightly in this case. The rest indicators remain at the level of the control variant. 
Table 4. Effect of late foliar fertilization with nitrogen on the chemical composition of bean seeds, in \% on dry matter (vegetation experiments).

\begin{tabular}{|l|c|c|c|c|c|c|}
\hline Treatments & $\begin{array}{c}\text { Total } \\
\text { nitrogen }\end{array}$ & Protein & Starch & $\begin{array}{c}\text { Ascorbic } \\
\text { acid, mg\% }\end{array}$ & $\begin{array}{c}\text { Dry } \\
\text { matter }\end{array}$ & $\begin{array}{c}\text { The } \\
\text { amount of } \\
\text { sugars }\end{array}$ \\
\hline $\begin{array}{l}\text { Control } \\
\text { (treated with } \\
\text { water) }\end{array}$ & 1.62 & 20.95 & 30.95 & 8.31 & 10.40 & 1.25 \\
\hline $\begin{array}{l}5 \% \text { solution } \\
\text { of } \mathrm{NH}_{4} \mathrm{NO}_{3}\end{array}$ & 1.63 & 21.06 & 31.05 & 7.28 & 11.67 & 1.20 \\
\hline $\begin{array}{l}10 \% \text { solution }^{2} \mathrm{NH}_{4} \mathrm{NO}_{3} \\
\text { of }\end{array}$ & 1.67 & 21.13 & 31.4 & 8.35 & 13.14 & 1.35 \\
\hline $\begin{array}{l}15 \% \mathrm{Solution}_{4} \\
\text { of } \mathrm{NH}_{4} \mathrm{NO}_{3}\end{array}$ & 1.72 & 24.39 & 33.8 & 8.92 & 12.92 & 1.39 \\
\hline
\end{tabular}

\section{Conclusions}

Foliar fertilization with nitrogen helps to increase the yield of beans by reducing the blind seed content and increasing the absolute weight of seeds in the beans.

Foliar top beans fertilization with ammonium nitrate slightly increases the content of total nitrogen, protein, starch and the total dry substances content in the seeds.

The total bean plants density per unit area of sowing consists of the number of branches per bush. On sparse crops in the middle of the plants flowering phase the total number of branches increases significantly due to improved conditions of plants nitrogen nutrition.

In the case of sparse crops, the introduction of nitrogen fertilizers can stimulate branching, although high doses should be used more carefully in this case, since before the formation of a sufficiently large biomass, rare crops achieve the depressing effect of excess nitrogen earlier than on normally thickened crops.

Thus, due to competition between plants, common in density, and even sparse crops, the potential genetically determined beans productivity is realized only to a small extent. The main factor for which bean plants compete during the emergence phase-the flowering beginning under normal cultivation conditions is the soil available nitrogen. Therefore, the rational use of nitrogen fertilizers leads to a more complete phenotypic manifestation of the genetically determined productivity of vegetable beans.

Taking into account all the above, we consider it necessary to recommend foliar top fertilization of vegetable beans with nitrogen in the phase of emergence- flowering beginning as a way to increase plant productivity.

\section{References}

1. E., Šarauskis, K. Romaneckas, V. Naujokienè, Improving energy efficiency and environmental mitigation through tillage management in faba bean production Energy 29 July, 209, Article 118453 (2020)

2. T. Bai, Y.-Y. Liu, Y.-J. Wang, Mixed nitrogen form addition facilitates the growth adaptation of legume plant to heavy metal contamination in degraded mining areas, Global Ecology and Conservation, Lindström and Mousavi 3 December 24, Article e01387 (2020)

3. K. Lindström, S.A. Mousavi, Effectiveness of nitrogen fixation in rhizobia, Microb. Biotechnol. 13, 1-22 (2019).10.1111/1751-7915.13517 
4. H. M. M. Abdel-Aziz, M. N. A. Hasaneen, A. M. Omer, Impact of engineered nanomaterials either alone or loaded with NPK on growth and productivity of French bean plants: Seed priming vs foliar application, South African Journal of Botany. 18 July, 125, 102-108 (2019)

5. L.V. Donchenko, T.N. Doroshenko, E.A. Krasnoselova, E.V. Konuhova, G.F. Petrik, Impact of technological scheme of apple tree cultivation on fractional content of pectin substances, In the collection of articles: IOP Conference Series: Earth and Environmental Science. Russian Conference on Technological Solutions and Instrumentation for Agribusiness, TSIA 2019, 012008 (2020) DOI: 10.1088/17551315/488/1/012008

6. A. A. Samuel, O. Asagba, Zinc-cadmium interactions instigated antagonistic alterations in lipid peroxidation, ascorbate peroxidase activity and chlorophyll synthesis in Phaseolus vulgaris leaves, Scientific African. 7 January, 11, Article e00688 (2021)

7. Effect of zinc foliar spray alone and combined with humic acid or/and chitosan on growth, nutrient elements content and yield of dry bean (Phaseolus vulgaris L.) plants sown at different dates, Scientia Horticulturae. 5 March 184, 101-105 (2015)

8. R. Sanches, P. Luciana, F. Brito, A. P. Araújo, Seeds enriched with phosphorus and molybdenum as a strategy for improving grain yield of common bean crop Field Crops Research. 20 September 136, 97-106 (2012)

9. G.M. Chaer, A.S. Resende, E.F.C. Campello, S.M. De Faria, R.M. Boddey, S. Schmidt, Nitrogen-fixing legume tree species for the reclamation of severely degraded lands in Brazil (Open access), Tree Physiology 31(2), 139-149 (2011)

10. E. Kisetu, N. Frederick, B. Patrick, A. Ndakidemi, Productivity of intercropping with maize and common bean over five cropping seasons on smallholder farms of Tanzania, European Journal of Agronomy, 14 November 113, Article 125964. (2019)

11. N. Katerji, M. Mastrorilli, T. Oweis, Faba bean productivity in saline-drought conditions European, Journal of Agronomy, June 35(1), 2-12 (2011)

12. J. Wilker, A. Navabi, I. Rajcan, F. Marsolais, B. Hill, D. Torkamaneh, K.P. Pauls, Agronomic performance and nitrogen fixation of heirloom and conventional dry bean varieties under low-nitrogen field conditions, Front. Plant Sci. 10, 952 (2019) 10.3389/fpls.2019.0095

13. Y. Reinprecht, L. Schram, F. Marsolais, T.H. Smith, B. Hill, K.P. Pauls, Effects of nitrogen application on nitrogen fixation in common bean production, Front. Plant Sci. 11, 1172 (2020)10.3389/fpls.2020.01172

14. S. J. Habinshuti, S. T. Maseko, F. D. Dakora, Effect of N-fertilizer application on the symbiotic N2 fixation by field-grown common bean (phaseolus vulgaris L.) in Eastern Cape Province, South African Journal of Botany 98, 179 (2015)

15. A.R. Schwember, J. Schulze, A. del Pozo, R.A. Cabeza, Regulation of symbiotic nitrogen fixation in legume root nodules, Plants 8, 33 (2019)10.3390/plants8090333

16. T. Oweis, A. Hachum, M. Pala, Faba bean productivity under rainfed and supplemental irrigation in northern Syria, Agricultural Water Management. 20 April, 73(1), 57-72 (2005)

17. A. S. A. Hegab, M. T. B. Fayed, M. A. A. Abdrabbo, Productivity and irrigation requirements of faba-bean in North Delta of Egypt in relation to planting dates Annals of Agricultural Sciences 59(2), 185-193 (2014)

18. M. Nassiri, M. Alireza, K. S. Amirmoradi, Determination of optimal strip width in strip intercropping of maize (Zea mays L.) and bean (Phaseolus vulgaris L.) in Northeast Iran, Journal of Cleaner Production, 106, 343-350 (2015) 